\title{
Collected Writings as Xylographs: Two Sets from the Bo dong pa School
}

\author{
Franz-Karl Ehrhard
}

During the expeditions of the Nepal-German Manuscript Preservation Project (NGM PP) to different parts of the Nepalese Himalaya quite a number of Tibetan block prints could be located and microfilmed, and the ensuing research of documenting and describing individual works and collections provided a platform for investigating the historiography of print in Tibet. It was in particular the tradition of producing Buddhist xylographs in the region of Mang yul Gung thang in south-western Tibet where a shift from a manuscript culture to a block-print culture could be observed and where questions could be raised concerning the introduction of this technology, and such issues addressed as craftsmanship, patronage structures and the choice of texts for reproduction as print editions. ${ }^{1}$

The strong presence of the Bo dong pa school of Tibetan Buddhism in the region of Mang yul Gung thang can be regarded as a positive force for the introduction and dissemination of the art of printing in the period, especially in the $15^{\text {th }}$ and 16 th centuries. The expertise of the Buddhist craftsmen in this region and period was highly influential in the development of further centres of printing in neighbouring areas. The starting point for the documentation of this local school is what was executed by a learned Bo dong pa monk and by a bKa' brgyud pa yogin, all of which could be identified and described on the

1 For the term "print culture" as a unifying concept characterized by certain traits such as standardization, dissemination and fixity of texts in early modern Europe, see Eisenstein (1979) and (1983). For the problems this understanding encounters in the historiography of print in early England's book culture and the proposal to use the term more in the sense of a result of manifold representations and practices, thus allowing us to reconstruct different print cultures subject to particular historical circumstances, consult Johns (1998, 6-28). See Schaeffer (2009, XI) for methodological challenges to the study of the culture of the book in Tibet.

(C) FRANZ-KARL EHRHARD, 2016 | DOI 10.1163/9789004316256_013

This is an open access chapter distributed under the terms of the Creative Commons Attribution-

Noncommercial 3.0 Unported (CC-BY-NC 3.0) License. 
basis of their biographies and the "printing colophons" (par byang) available at the time. ${ }^{2}$

In the following I want to take a closer look again at this particular period in south-western Tibet and the efforts undertaken to execute xylograph editions of the "Collected Writings" (gsung 'bum / bka' 'bum) of two of the masters of the Bo dong pa school, who enjoyed the support of the court at the royal capital, rDzong dkar. We should thus be able to observe how the shift from a manuscript culture to a block-print culture actually took place and consider what it meant to have texts that had been copied by scribes printed out - in other words, to have manuscripts replaced by xylographs.

\section{$2 \quad$ Collected Writings as Prints}

The early history of xylographic printing of Tibetan texts, the corpus of printed texts and the question of patronage have been laid out in some detail on other occasions, with note being taken of the importance in this regard of the relationship that existed between Tibetan Buddhist religious hierarchs and the Mongolian court in the 13th century. These religious teachers belonged to the Sa skya pa and bKa' brgyud pa schools. During the time of the Mongolian occupation xylographs of relevant texts were being carved in China proper; such xylographs are known among Tibetan authors as "Mongolian prints" (hor par $m a$ ). It has also been observed that the very first Tibetan treatises ever committed to printing blocks in the Tibetan cultural area were the collected writings of two masters of the sMar pa bKa' brgyud school from sMar khams in eastern Tibet; this is known from the chronicle of the abbots of Tsom mdo gnas gsar, a monastery of this school founded in the year 1200. Although the actual xylographs of the writings of Chos rje sMar pa Shes rab ye shes (1135-1203) and 'Gro mgon Rin chen dpal (1170-1249), are not available, we know from this evidence that the technology of block printing was in place in Khams around 1200 and

2 For the kingdom of Mang yul Gung thang, the spiritual ties of its individual rulers with Bo dong Chos rje Phyogs las rnam rgyal (1375-1451) and the production of Buddhist classics in the 15th and 16th centuries, see Ehrhard (2000a, 12-16). Consult Smith (2001, 170-208) for an overview of works of Bo dong Pan chen dealing with Buddhist literary and practical arts. For the religious careers of the Bo dong pa monk Chos dbang rgyal mtshan (1484-1549) and the 'Ba' ra ba bKa' brgyud pa yogin Nam mkha' rdo rje (1466-1553) and their printing activities, see Ehrhard (2000a, 23-66); see also Ehrhard (2012, 150-167) for the life of gNas Rab 'byams pa Byams pa phun tshogs (1503-1581) and his contribution to Buddhist block printing in the region. Refer to Diemberger (2009, 114-115) and Diemberger (2012, 29-34) for the present-day revival of the Bo dong tradition. 
that it was the collected works of these two Buddhist masters for which the technology was first employed. ${ }^{3}$

The earliest large printing project in Central Tibet to which reference survives is an edition of many works of rJe Tsong kha pa Blo bzang grags pa (13571419), who took a personal interest in printing in the final years of his life. The work was executed on orders of the Phag mo gru pa ruler Grags pa rgyal mtshan (1374-1452), and according to biographical sources relating to him the responsibility for seeing the project through to completion was deputed to a minister of Gong dkar. The disciples and patrons of rJe Tsong kha pa saw their work as "fulfilling the intentions" (dgongs rdzogs) of the master. During the early $15^{\text {th }}$ century and the following decades other nobles sponsored the carving of individual works of the founder of the $\mathrm{dGe}$ lugs pa school; these included the powerful sNe'u/sNel pa family. These xylographs became known as "old dGa' ldan prints" (dga' ldan par rnying), inasmuch as the blocks were originally carved in the monastery of dGa' ldan or else were eventually moved there. ${ }^{4}$

3 See van der Kuijp (2010, 449-455) for a brief overview of the early history of xylographic printing in Tibet and the religious chronicle of the sMar pa bKa' brgyud pas. The work has also been used as a source for documenting the presence of Sa skya pa and bKa' brgyud pa religious hierarchs in sMar khams; consult van der Kuijp (2007, 107 \& 122-123). For the biographies of 'Gro mgon Rin chen dpal and his successor Chos rje sTon pa Tshul khrims gzhon nu dpal (1197-1277), who were responsible for executing the blocks, see sMar pa bka' brygud kyi rnam thar phyogs bsgrigs, Chengdu: Si khron mi rigs dpe skrun khang, 2006, 82-122; the references to the printing can be found ibid., p. 97.13-14 (chos rje'i gsung rnams phyogs gcig tu shing spar brkos), and p. 121.15-16 (chos rje ston tshul 'dis 'gro mgon rin chen gyi gsung 'bum rnams spar shing brkos te). The question of a possible Chinese influence on the Tibetan custom of producing collected writings at a time when eminent Tibetan masters had close relations with the Chinese court, and of exactly when the printing technology was introduced to Tibet, is raised by Kragh $(2013,381)$. Compare Sernesi (2013/2014 [2015]: 475ff) for the construction of literary oeuvres of Tibetan masters, including the collected sayings of sGam po pa bSod nams rin chen (1079-1153), the founder of the Dvags po bKa' brgyud school.

4 For written references to the earliest printings of the works of rJe Tsong kha pa and the patrons involved in these projects, see Jackson (1990, 107-108); see also Jackson (1989, 12) for the powerful sNe'u/sNel pa family (especially Drung chen Nam mkha' bzang po, a great patron of the master). Consult Sørensen and Hazod $\left(2007,49^{-52}\right)$ for the role of the sNe'u/ sNel family (and in particular the 2nd sNe'u rdzong dpon Nam mkha' bzang po, fl. ca. 14001430) as pioneer patrons of the dGe lugs pa school in sKyid shod. An illustrated print of a manual on Nāropa's Six Yogas, based on teachings delivered by rJe Tsong kha pa in 1419 and produced under Phag mo gru pa patronage in the first half of the 15th century has been described in Sernesi (2010, 143-149). A reproduction of an early print of a tantric commentary by rJe Tsong kha pa (dating from 1428) brought out by the nobles of sTag rtse in 'Ol kha for the 
During this period, too, writings of further eminent Tibetan teachers were carved on wooden blocks, including ones of Chos rje Phyogs las rnam rgyal (1376-1451), the founder of the Bo dong pa school. It is known that early prints of his writings were produced in the myriarchy of La stod lHo in south-western Tibet through the efforts of the ruler Ta'i Si tu lHa btsan skyabs and that the master himself was personally involved in the production of prints of Buddhist canonical texts during his residence at the Shel dkar chos sde at the beginning of the $15^{\text {th century. }}{ }^{5}$

Concerning the collected writings of Phyogs las rnam rgyal, it is said that they were reproduced in Mang yul Gung thang during the reign of Khri lHa dbang rgyal mtshan (1404-1464), who regarded Bo dong Chos rje as his main spiritual preceptor. These prints included the three different versions of the De nyid 'dus pa, the final masterpiece and legacy of Bo dong Chos rje. None of these prints seems to have survived, but at least other xylographs of individual writings of the founder of the Bo dong pa school are available, including the smallest and fourth text of the De nyid 'dus pa cycle; according to the printing colophon this latter work was printed at the border between dBus and gTsang, the patrons responsible for the project being two rulers of the myriarchy of Yar 'brog, namely Khri dpon Nam mkha' bzang po and his nephew Khri dpon Kun dga' rgyal mtshan. ${ }^{6}$

long life of the Phag mo gru pa ruler Grags pa rgyal mtshan is now available; see dPal 'khor lo sdom pa bde mchog bsdus pa'i rgyud kyi rgya cher bshad sbas pa'i don gsal ba, 167 fols., in "Bod kyi shing spar lag rtsal gyi byung rim mdor bsdus," Xinhua: Bod ljongs bod rig dpe rnying dpe skrun khang, 2013, 15-17.

5 For the xylographs of the Tibetan translation of Haribhadra's Abhisamayālañkāra-āloka, 90 fols., from the year 1407, and for the work dPal de kho na nyid 'dus pa las rgyud sde spyi'i rnam par bzhag pa, 259 fols., a general exposition of the Tantra classes by Phyogs las rnam rgyal printed at the Shel dkar chos sde, see "Bod kyi shing spar lag rtsal gyi byung rim mdor bsdus" (as in note 4), pp. 4-6 \& 10-11. A short "catalogue" (dkar chag) to the former work by Bo dong Pan chen can be found in "Bo dong phyogs las rnam rgyal gyi gsung 'bum gsar rnyed skor," Beijing: Khrung go'i bod rig dpe skrun khang, 2009, vol. 4, pp. 301-303. Compare Diemberger \& Clemente $(2013,133)$ on the importance of these works as documentary sources for the historiography of printing in La stod lHo. In the last decade of the 14th century Bo dong chos rje had also contact with the Phag mo gru pa ruler Grags pa rgyal mtshan; see Czaja (2013, 215-216).

6 Concerning the reference to 15th-century prints of the collected writings of Phyogs las rnam rgyal in the region of Mang yul Gung thang, see Ehrhard (2000a, 12-13); and Everding (2000, 128-129) for the relevant section in the chronicle of the rulers of Mang yul Gung thang, written by Kah thog Rig 'dzin Tshe dbang nor bu (1698-1755). Consult Chok Tenzin Monlam (2005, 97-98) regarding the xylographs of the De nyid 'dus pa cycle and relevant references to the 
Single works containing teachings of the mentioned cycle of the Bo dong pa school were also printed in southeastern Tibet, one of them dating from 1482. In the latter's printing colophon it is noted that it had been completed in order to fulfil the final intentions of the "sovereign who upholds the doctrine" (bstan 'dzin gong $\mathrm{ma}$ ); among the sponsors, the ruling family of the myriarchy of Bya is mentioned in the first place. While the epithet is a reference to the Seventh Phag mo gru sDe srid Kun dga' legs pa (d. 1482), the latter ruler of the myriarchy of Bya can be identified as Bya pa khri dpon bKra shis dar rgyas (d. 1499). The xylograph was executed at gSang sngags bDe chen gling, located at the sacred site of gNas chen Tsa ri tra, under the supervision of one Byams chen gyi btsun pa 'Phags pa. ${ }^{7}$

biography of Phyogs las rnam rgyal as a source for further prints; details of these prints can be found in Diemberger, Wangdu, Kornfeld \& Jahoda (1997, 41-97). The lone surviving copy of the smallest De nyid 'dus pa text (170 fols.) is housed in the British Library under pressmark Tib I.156. Another print of an individual work by Phyogs las rnam rgyal, one supported by Khri dpon Kun dga' rgyal mtshan, can be dated to the year 1446; see rJe thams cad mkhyen pa phyogs las rnam par rgyal bas mdzad pa'i kun rig gi cho ga'i de nyid rnam par nges pa, 42 fols., in "Bod kyi shing spar lag rtsal gyi byung rim mdor bsdus" (as in note 4), pp. 18-19. Compare 'Jigs bral gyi slob dpon phyogs thams cad las rnam par rgyal ba'i zhal snga nas mdzad pa'i rgyud sde'i rnam par bzhag pa, 178 fols., ibid., pp. 23-24; this is a further xylograph, executed in Yar 'brog in the year 1468. A work related to the De nyid 'dus pa cycle and composed in the 15th century was produced in Zur mtsho, a principality to the east of Mang yul Gung thang; see dPal de kho na nyid 'dus pa'i snying po chos spyod rab tu gsal ba, 176 fols., ibid., pp. 28-29.

7 The print bears the title Zhal gdams de nyid 'dus pa las / rdo rje lus kyi sbas bshad / rin chen snying po, 20 fols., and can be found in "Bo dong phyogs las rnam rgyal gyi gsung 'bum gsar rnyed skor" (as in note 5), vol. 2, pp. 625-664. Concerning the conflicting dates of the death of the Seventh Phag mo gru sDe srid, see Ehrhard (2002, 26, 22); see also Ehrhard (2002, 30) for the residence of the ruler Bya khri dpon bKra shis dar rgyas in [g]Nyal and the editing and carving of the "Blue Annals" (deb ther sngon po) in the same year, i.e. 1482. Another individual work of Phyogs las rnam rgyal was printed during this period in the southern region of gTam shul in the region of lHo brag. See rGyud sde bzhi'i lha tshogs la bstod pa 'dod pa'i 'jo ba, 91 fols., in "Bod kyi shing spar lag rtsal gyi byung rim mdor bsdus" (as in note 4), pp. 25-27. This xylograph was executed in 1477 after the demise of the Second 'Brug chen rGyal ba'i dbang po (1428-1476) by a member of the family of mNga' bdag Nyang, namely the treasure discoverer Nyi ma'i 'od zer (1124-1192). For the significance - as exemplified above - of offering a print of a specific work as a memorial to a deceased person or for the long life of prominent living figures, see Schaeffer (2011, 461-462). 
Another member of the royal house of Mang yul Gung thang who honoured Phyogs las rnam rgyal as his spiritual preceptor was Khri rNam rgyal lde (14221502). According to the historiographical sources, he acted as patron for a number of printing projects and also supported the production of manuscript copies of Buddhist texts. This we can see in the case of further collected writings from the Bo dong pa school. I may refer to the works of dPal ldan Sangs rgyas (1391-1455), a disciple of Phyogs las rnam rgyal. The following quotation is from the biography of the bTsun pa Chos legs (1437-1521), another Bo dong pa master, who undertook the task of reproduction. It illuminates the difficulties of obtaining the necessary materials for such a project, and also the role of the ruler in finalizing it:

Then, in the summer of the horse-year [=1474] the thought arose in my mind: "What if I prepare a [set of the] Collected Works of the great mKhas grub [dPal ldan Sangs rgyas]?” When in following [days] I made further enquiries with persons who were like close friends [to him], one dGe sbyor Chos nyid by name, who had before been the servant of the great mKhas grub [dPal ldan Sangs rgyas], [acting as his] assistant for the offering rituals and so on, spoke [the words]: "In conformity with [the size of] that [undertaking], I present ten loads of barley as working support for the production of the Collected Works." And as it happened, I decided to execute the plan and complete it by all means. Although I had at that time no material goods at all, after dGe sbyong dPal legs, a friend from earlier times when I had taken the monastic vows, offered a woollen cloth and seventy small pieces of coral, because of that offering I looked around how best to purchase paper. When there was still prosperity in the region within my purview, some ten close friends went out [to look for paper] during a begging tour to [the valley of] bTsum, but still they could not get any proper paper at that time.

Then, from the winter of the sheep-year [=1475], after such paper was acquired from sKyid grong, two scribes wrote out from the beginning the two great commentaries on the difficult points of the 'Dul (b)rgyan and the Phar phyin. Then the sovereign Khri rNam rgyal lde himself spoke [the words]: "I shall act as donor for the production of the 'Dul (b)rgyan", and he gave nine loads of barley. As in the summer [of the next year] one more scribe was added, [the work] was completed and the nine volumes of the Collected Writings of the great mKhas grub [dPal ldan Sangs rgyas] and the biographies of the All-knowing Bo dong [Pan chen], [i.e.] the Yar 
'brog ma and the Ngag dbang ma, [these] two, [together with] the biography of the great mKhas grub [dPal ldan Sangs rgyas] by the great scholar dPal ldan dar (1424-1510), [these] three, were made into one volume. [All in all] I executed ten volumes, which [thus] made their appearance, and they rest [up till now] in [the monastery of] mNgon dga: ${ }^{8}$

The mentioned monastery - located to the south-west of rDzong dkar, the capital of the rulers of Mang yul Gung thang - has already been identified as an important stronghold of the Bo dong pa school in the royal domain, and as a residence of teachers including dPal ldan Sangs rgyas (its first abbot) and dPal ldan dar. It was also the institution where bTsun pa Chos legs had received his monastic training. The same master was not only able to compile and edit the collected writings of dPal ldan Sangs rgyas, but also completed in the same year a manuscript edition of the "Collected Tantras" (rgyud 'bum), once again with the material support of the king Khri rNam rgyal lde. In the year 1477 he was urged to come in person to rDzong dkar, and this stay resulted in the production of a complete manuscript $b K a$ ' 'gyur written out by thirty scribes - a project supervised by dPal ldan dar (the second abbot of mNgon dga') in a special temple erected in the royal palace during this time. ${ }^{9}$

On the basis of these details it is possible to see how collected works were produced in Mang yul Gung thang both as block prints and as manuscripts in the 15th century and the extent to which such projects were supported by

8 For this passage from the biography of bTsun pa Chos legs, see Ehrhard (200ob, $\mathrm{X}-\mathrm{XI}$ ); compare dPal ldan bla ma dam pa chos legs mtshan can gyi rnam thar yon tan 'brug sgra [= Appendix I, ka], fols. 58/6-59a/2. A biographical sketch of dPal ldan Sangs rgyas is contained in another work of the same author; see Thugs rje chen po'i dmar khrid che tsham lnga $p a$ [= Appendix I, kha], fols. 14b/2-18a/3. Concerning an encounter between dPal ldan Sangs rgyas and Bo dong Chos rje Phyogs las rnam rgyal in Glo bo, present-day Mustang in the Nepalese Himalayas, see Diemberger, Wangdu, Kornfeld \& Jahoda $(1997,77)$.

9 See Ehrhard (200ob, XI-XII) for these further productions of manuscripts of Buddhist canonical collections in Mang yul Gung thang during the reign of Khri rNam rgyal lde. The temple called [gSang sngags] lHa khang dmar po and the existence of a handwritten bKa' 'gyur is also noted in the chronicle of the royal house; see Everding (2000, 138-139) and Ehrhard (2000a, 14). The same source refers in the same context to the printing projects of Khri rNam rgyal lde, including the Mani bka' 'bum and the Mi la'i bka' 'bum. This seems to be a telescoping of later events and probably signifies simply the general support printing projects enjoyed from the rulers; see Ehrhard (2013, 45, note 5). Compare Diemberger \& Clemente (2013, 132-133) for a similar observation and details of a reproduction of the collected works of Bo dong Phyogs las rnam rgyal by Chos kyi sgron ma (1422-1455/56), a sister of Khri rNam rgyal lde and personal disciple of the master; this edition existed as a whole obviously only in the form of manuscripts. 
the patronage structure of kings. In order to see how further manuscript collections were produced and how the transformation of individual texts into the xylographic medium occurred, I shall look more closely into the religious career of bTsun pa Chos legs to see which texts were chosen to be reproduced as prints.

\section{$4 \quad$ Mahāmudrā Works in Mang yul Gung thang}

It has already been documented that bTsun pa Chos legs was an eclectic Buddhist master, one who had developed a particular interest in the Mahāmudrā doctrine. This interest had been stirred by a Sa skya pa teacher called mKhas btsun dPal 'byor bzang po (15th cent.), who hailed from an influential family at the court of the rulers of Glo bo. It was from him that bTsun pa Chos legs had received the cycle known as the Ri chos skor gsum of rGyal ba Yang dgon pa (1213-1258), and soon afterwards he had made the teachings available in the form of a manuscript edition of the collected writings of the 'Brug pa bKa' brgyud pa master; these activities can be dated to the year 1497. It is interesting that only three decades later this mgur 'bum collection was further distributed in the form of a xylographic print; it was Chos dbang rgyal mtshan, the previously mentioned Bo dong pa monk who counted among the close disciples of bTsun pa Chos legs, who conceived and carried out this undertaking. ${ }^{10}$

In the years 1501 to 1504 the master from mNgon dga, now settled at the hermitage of Chab rom near the village of Rud in the southern part of the kingdom, composed his own text on the Mahāmudrā doctrine, consisting of five chapters. Ten years later, in 1514, the manuscript was then printed as a xylograph in mTsho rkyen, another hermitage located in the vicinity of Chab rom. This print was executed during the joint reign of King Khri Kun dga' rnam rgyal lde (d. 1524) and his nephew Nam mkha' rgyal mtshan. It may be noted that

10 The transmission of the Mahāmudrā doctrine from mKhas btsun dPal 'byor bzang po and the production of a manuscript set of the mgur 'bum collection of rGyal ba Yang dgon pa is described in the biography of bTsun pa Chos legs; see Ehrhard (200ob, XIII) and the text (as in note 8 ), fols. $77 \mathrm{~b} / 4-78 \mathrm{~b} / 4$ \& $90 \mathrm{~b} / 2$. The print of the same collection in two volumes by Chos dbang rgyal mtshan after the death of his teacher was the first of his major printing projects; see $m$ Tshan ldan bla ma dam pa mnyam med chos dbang rgyal mtshan gyi rnam par thar pa / rin po che nor bu'i phreng ba [= Appendix II, ka], fol. 53a/4-b/3, and Ehrhard (2000a, 29-30). For the printing colophon of this collection, consult Ehrhard (2000a, 88-93). 
among the six carvers summoned to mTsho rkyen, one finds the "master scribe of the ruler" (sde pa'iyig dpon), dPal ldan rgyal po; this points up that the main craftsmen came from the court of the rulers of Mang yul Gung thang.

The master composed a further two works on the Mahāmudrā doctrine, but in contrast to the first composition they not long afterwards appeared in a print medium. The two works were executed as xylographs in the year 1516, and once again the royal scribe is highlighted among the carvers. A fourth and final work concerning the Mahāmudrā doctrine was printed in 1521 after the death of bTsun pa Chos legs; in its printing colophon, the castle of rDzong dkar is given as the place where the carving of the blocks was performed. ${ }^{11}$

From the biography of Chos dbang rgyal mtshan, who had been in the company of his teacher during the period under discussion, it is possible to learn how the royal support for these printing projects came about. The year 1521 saw both teacher and disciple in rDzong dkar, following an invitation-cumrequest by Khri Kun dga' rnam rgyal lde to bTsun pa Chos legs to come and offer instruction on the Mahāmudrā doctrine. The final teachings of the Bo dong pa master were thus delivered at the royal residence. Among the recipients one finds once again the ruler, his nephew Nam mkha' rgyal mtshan and the abbot of mNgon dga'. After the death of bTsun pa Chos legs, his disciple Chos dbang rgyal mtshan was responsible for the necessary funeral rituals, but he also took it upon himself to execute xylographic prints, among them the four mentioned Mahāmudrā works. ${ }^{12}$

Like the collected writings of rGyal ba Yang dgon pa - of which a great number of manuscript versions circulated at that time, according to the testimony of Chos dbang rgyal mtshan - the Mahāmudrā works of the Bo dong pa master were executed as xylographs only when the time was ripe, namely only after royal support had been secured from the court at rDzong dkar; such support ensured the expertise of Buddhist craftsmen like the royal scribe. We may now turn to the mentioned sources in order to see what they have to say about how exactly the collected writings came into being as a complete set.

11 The details concerning the writing out and printing of the four Mahāmudrā works of bTsun pa Chos legs can be found in Ehrhard (200ob, XIV-XVI); for the individual sections in the biography, see the text (as in note 8), fols. 109b/6-110a/1 and 110a/4-5. The printing colophons of these xylographs are reproduced in Ehrhard (2000a, 83-87).

12 For the ten-year period from 1511 to 1521 , which Chos dbang rgyal mtshan spent in the company of his teacher and in the printing of the mentioned works (and further xylographs of the writings of bTsun pa Chos legs), see Ehrhard (2000a, 24-28); compare the biography (as in note 10), fols. 3ob/6-51b/2. During the pair's first stay in rDzong dkar the king and his court received also the transmission of the Mani bka' 'bum, while among the xylographs produced in 1521 one finds the so-called "Royal Print" of this collection; see Ehrhard (2013, 144-156). 
After Chos dbang rgyal mtshan had obtained ordination as a Buddhist monk from Rab 'byams pa dKon mchog rgyal mtshan (15th/16th cent.), the abbot of mNgon dga', he spent the time up to the end of 1517 in strict seclusion at his favourite hermitage of Kun gsal sgang po che in the region of gTsang to the south-west of rDzong dkar. Soon afterwards he was summoned by bTsun pa Chos legs, and he took advantage of the occasion to copy out the collected writings of the master into six volumes of manuscripts, while receiving during this same time "reading authorization" (lung) for these volumes from bTsun pa Chos legs:

Afterwards [Chos dbang rgyal mtshan] made a petition: "For the benefit of the Buddhist doctrine and the disciples following it, we two, [master and disciple], should execute these former compositions [of yours] as volumes (glegs bam) of [a set of your] collected writings", whereupon [bTsun pa Chos legs] replied: "This is the very way you go about things! But since there may be benefit to others [through such work], perform [it]!" Having obtained permission, [Chos dbang rgyal mtshan] completed six books (po ti) [of the master's writings], which were for the greater part manuscripts of the Precious One himself. [These volumes] now rest in [the monastery of] rTa dga'.

On these occasions, too, reading authorization was given for the large and small instructional texts of the Mahāmudrā [doctrine], the large and small [texts] on the difficult points relating to obtaining spiritual progress in that [doctrine]; [the work] Nyams yig mani lu gu brgyud, [i.e. the text on] how to keep one's spiritual experience on track; [and of the work] Grol lam gsal bar byed pa snying gtam rin po che'i phreng ba) [with its sections on] the general framework, the presentation of the base (where the Mahāmudrā of the existing ground is established), the presentation of view, meditation and conduct (where the Mahāmudrā of the path of meditation is established), and that of the fruit (where the Mahāmudrā of the result to be realized is shown). [At the same time,] too, the comprehensive reading authorization for the six books of the precious collected writings [of bTsun pa Chos legs] was given. ${ }^{13}$

13 See the biography of Chos dbang rgyal mtshan (as in note 9), fol. 49a/1-b/1 (de nas bdag gnyis kyis / bstan pa dang rjes 'jug gi gdul bya rnams kyi don du / sngar gyi gsung rtsom 'di rnams kyang / bka' 'bum glegs bam du bsgrub par bka' gnang zhus pas / khyed rang gi byed lugs kyang yin / gzhan la phan paryang srid pas bsgrubs shig gsung / dgongs pas khrol / rin po che rang gi phyag ris gtso che ba'i po ti drug bsgrubs pa de / da ltar rta dga' na bzhugs 
In the case of the collected writings of bTsun pa Chos legs, we can see how the author's own handwritten material was initially copied and transformed into a manuscript edition by a disciple trained in the art of different scripts and already experienced in printing the master's compositions through his association with the same Buddhist craftsmen who had executed the first two texts of the Mahāmudrā doctrine as xylographic prints. We may now take things a step further by observing how the writings of the Bo dong pa teacher in their entirety were made available in the form of printed texts.

Among the disciples who were responsible for printing the master's writings at the time of the funeral ceremonies at the royal residence at rDzong dkar in $15^{21}$ was one 'Jigs med bzang po. He was the disciple who had requested bTsun pa Chos legs to relate the course of his life and had written down his narrative (an important literary source for the history of south-western Tibet and its nomadic regions), which took events up to the year 1520 . At the beginning of the autobiography we find a discussion between bTsun pa Chos legs and 'Jigs med bzang po about the need to make a mask from a cast of the master's face and an edition of his collected writings. Some of the statements echo ones which the master had earlier addressed to Chos dbang rgyal mtshan with regard to much the same issues. What comes out here more clearly is the fact that prints of the master's writings that had already been produced were the starting point for considering a print edition of all his compositions, including the biography:

Further, ['Jigs med bzang po] made a petition: "If one also compiles a [set of] collected writings when the teacher is [still] in good health, the gen-

so / de dag gi skabs su yang / phyag rgya chen po'i khrid yig che chung / de'i bogs 'don dka' ba'i gnas che chung / snyams skyong tshul nyams yig ma ṇi lu gu brgyud / spyii khog phubs I gnas pa gzhi'i phyag rgya chen po gtan la 'bebs pa gzhi'i skabs rnam par gzhag pa / bsgom pa lam gyi phyag rgya chen po gtan la 'bebs pa lta sgom spyod pa'i skabs rnam par gzhag pa / grub pa 'bras bu'i phyag rgya chen po ston pa 'bras bu'i skabs te / grol lam gsal bar byed pa [49b] snying gtam rin po che'i phreng ba'i khrid lung rnams gnang zhing / bka' 'bum rin po che po ti drug pa'i lung yang yongs su rdzogs par gnang ngo). See Ehrhard (2000a, 26) for the context of these events in the life of Chos dbang rgyal mtshan; concerning the monastery of rTa dga' (also spelt rTa sga or lTas dga'), another of the Bo dong pa school's foundations, consult Cüppers \& Ehrhard (2008, 18, note 2); concerning its early history in particular, see Vitali (2012, 74-78). 
eral order [of the volumes] will be perfect. Also, concerning each [single volume], a properly written [copy] will come out [of it]!" Similarly, a further request was put [to bTsun pa Chos legs]: "By having the cycle of the Mahāmudrā [doctrine] executed [already] as a print in one volume, [in] cut [paper format], it is completely done. Should the other [writings] be collected into three books ( $p o t i$ ) similar [in format] to cut [paper], in other words, these three [volumes], shall we three, [i.e.] we two friends together with the bhikșu dBang phyug dpal ldan, execute each volume [as a print]?"14

Then [the master] replied: "There is no need to produce a mask from my [face]. Even if you were to produce one, later one will say something like: 'Although the mask resembles the teacher in one way, in part it does not. It would be better to destroy [the mask] and erect a statue of such a person!' Therefore it's not worth the trouble to produce a mask for me. If you collect my compositions into books ( $p o t i$ ), you would be following the way you [normally] do things. The most important thing about my biography is this: as people are of various kinds, it is possible that benefit will later arise for those who follow [the Buddhist doctrine]!" With that he gave permission, and the collected writings were compiled into four volumes; [together with the Mahāmudrā volume and the biography] they represent the six volumes in cut [paper format] which exist up to now..$^{15}$

14 The term sa dras can be understood here as referring to the paper size or format. Compare the following passage from the work She bam chen mo"i dper brjod in "Zhal lce phyogs btus", Xinhua: Bod ljongs mi dmangs dpe skrun khang, 1987, p. 143.10-13: "In keeping with [the fact that] the size of the cut paper was commissioned and manufactured in mTsho sna, it is called 'dGa' ldan paper', of which two [sets] each came forth." (... mtsho snar mngag bzos kyi shog bu dras tshad dang mthun pa gnyis re thon pa'i dga' ldan shog zer $b a \ldots)$. The context is the production of deluxe editions of the $b K a^{\prime}$ 'gyur; see Cüppers (2010, 116-117).

15 See the biography of bTsun pa Chos legs (as in note 8), fols. $4 \mathrm{~b} / 1-5 \mathrm{a} / 2$ (gzhan yang sku khams bzang ba ka bka' 'bum zhig kyang bsgrigs na / spyi'i go rims legs shing / rang rang gi thad du yang yi ge dag pa cig 'ong par mchis pas / bka' gnang bzhu zhing / de la yang phyag chen gyi bskor sa dras po ti gcig par du bsgrubs pa 'dis tshangs pa gda' / gzhan rnams 'di dang dras mnyam pa'i po ti sum (= gsum) du 'du lags sam / gsum po de bdag grogs mched gnyis / dge slong dbang phyug dpal ldan pa dang gsum gyis re re sgrub / de ltar bka' gnang ba zhu zhus pas / nga'i'dra 'bag bzhengs pa la dgos pa med / bzhengs kyang phyis 'di'dra ba bla ma su 'dra gcig gi 'dra 'bag yin kyang cha mi 'dug / 'di bshig nas che ge mo'i sku bzhengs pa drag zer ba las mi 'od pas 'dra 'bag bsgrubs pa la don med / nga'i brtsams chos rnams glegs bam du bsgrigs na nyid cag rang gi yang byed lugs su 'gro zhing / [5a] nga'i rnam thar gyi gtso bo 'di pa ka yin / sems can mos pa sna tshogs pa yin pas / phyis rjes su'jug pa phan pa 'byung bayang srid gsung bka' gnang nas / bka' 'bum bsgrigs pas po ti bzhi ma 'dus par / 
The question of casting a mask of bTsun pa Chos legs arose in the year 1518 when Buddhist craftsmen, including the "old master artist of the king of Gung thang" (gung thang rgyal po'i bla [= lha] bzo pa dpon rgan po) erected a "Mahābodhi stūpa" (byang chub chen po'i mchod rten) and a statue of Buddha Saakyamuni at the hermitage of Chab rom phug. Both 'Jigs med bzang po and Chos dbang rgyal mtshan supervised this project, and afterwards they proposed the idea of casting a mask of bTsun pa Chos legs from the gold which was left over. At the same time, the request was made to put together the collected writings obviously by Chos dbang rgyal mtshan, who went on to produce a manuscript version in six volumes.

From the narrative penned by'Jigs med bzang po, we can see that the volume of the three texts of the Mahāmudrā doctrine, already brought out as a xylograph edition, played a role in the compilation of the remaining texts, raising at it did the question whether the latter should take the form of manuscripts or be executed as xylographs by the two mentioned disciples along with dBang phyug dpal ldan, another Bo dong pa monk. It is interesting that bTsun pa Chos legs left this decision up to his disciples. We know at least that by 1525 the biography had finally been printed as the first volume in Chab rom phug; there too, and in the same year, the second volume, devoted to the Mahākarunika teachings transmitted by the master, was also executed as a xylograph. ${ }^{16}$

The four mentioned volumes of the collected writings of bTsun pa Chos legs seem to encompass the remaining works, that is, everything excluding the biography (marg. Ka) and the works on the Mahāmudrā doctrine. As the volume containing the Mahākarunika teachings (marg. Kha) is extant, there are three volumes and their individual titles which still remain to be identified. Two of

da lta sa dras po ti drug bzhugs pa 'diyin). See Ehrhard (200ob, XVI XVII) for a first assessment of the compilation of the collected writings of bTsun pa Chos legs. The mentioned friend of 'Jigs med bzang po is none other than Chos dbang rgyal mtshan, who was also involved in the execution of the print of the biography. For the printing colophon, see Ehrhard (2000a, 95-100). For the biography of bTsun pa Chos legs as a most important historical source for the history of south-western Tibet, see Everding (2000, 223-228).

For the events in Chab rom phug which led to the questions addressed to the eighty-oneyear-old teacher about relating the story of his life and the compilation of his writings, see the biography (as in note 8 ), fols. $3 \mathrm{~b} / 6-4 \mathrm{~b} / 1$. The second volume bears the title Thugs rje chen po'i dmar khrid don tshan lnga pa [= Appendix I, kha]; for the printing colophon, see ibid., fols. 125b/6-126a/6. For the full details, the reader is referred to the colophon of the biography, where it is stated that material support for this project came from the same source as the former one (par byang rnam thar nyid las rtogs par byos). For the lineage of the Mahākarunika teachings and the short biographies of the lineage holders, consult ibid., fols. 3 b/5-23a/3, and Ehrhard (2000c, 201-204). 
these must have contained the writings of the master on the Madhyamaka and rDzogs chen doctrines; up to now the original xylographs of these works have not yet surfaced, but at least manuscript versions are available. The third volume seems to have consisted of miscellaneous writings, of which two individual texts (marg. Ca) have come down to us. As the "catalogue" (dkar chag) of the complete set of collected writings has not yet surfaced, for the time being only a provisional list can be provided (see Appendix I).

\section{$7 \quad$ Printing the Works of Chos dbang rgyal mtshan}

It has been shown that in the case of the collected writings of bTsun pa Chos legs the effort to compile and edit this master's compositions started already in the final phase of his life, even if they bore final fruit only after his death. In any case, his disciples proved faithful to the task of "fulfilling the intentions" of the master, as the standard formula goes. We have seen that both manuscript and block-print versions were produced, and that the latter (with support from the royal court of Mang yul Gung thang) debuted with xylographs of works on the Mahāmudrā doctrine. In the following I shall look into how the collected writings of Chos dbang rgyal mtshan, the Bo dong pa monk known for his artistic and editorial skills, were made available as printed texts.

It is known that a set of the monk's complete writings were collected soon after his death in 1549 and that in the year $155^{1}$ a first volume, covering three individual works, was printed at the hermitage of Kun gsal sgang po che. The catalogue of the complete three-volume collection is available. It was produced in the following year by the same disciple of Chos dbang rgyal mtshan who had been responsible for carving the collected writings on printing blocks. This xylograph edition begins, like that of bTsun pa Chos legs's works, with a biography of the master. ${ }^{17}$

17 For the compilation of the collected writings of Chos dbang rgyal mtshan and the printing of the complete set, see Ehrhard (2000a, 50, note 46) The first volume contains the biography, the spiritual songs and minor religious writings, while of the works of the remaining two volumes only two texts are available; see mTshan ldan bla ma dam pa mnyam med chos dbang rgyal mtshan gyi bka' 'bum dkar chag mun sel sgron me, fols. 2a/4-3b//4 [= Appendix II]. Attention should be drawn to the list of contents of the third volume, for it mentions a catalogue of the collected writings of bTsun pa Chos legs and another one of the collected writings of Bla ma Zhang g.Yu brag pa brTson 'grus grags pa (1122-1193), the transmission of which was also in the hands of the master of the Bo dong pa school. 
In order to show how this set of collected writings had been conceived when the author was still alive, the section of catalogue which follows immediately after the actual table of contents and initial verses may be cited:

Thus the immaculate speech of the Noble One, the incomparable glorious teacher (i.e. Chos dbang rgyal mtshan), this powerful king of a precious [set of] collected writings - concerning [these] blessings they were compiled in the actual presence [of the master]. When [the work] Grub mtha' gshags ral [= Chos thams cad kyi spyi babs gshags ral chen mo] had been written out in his actual presence, the request was put to the Precious One: "Up to now [even] some of the treasure-teachings of the Precious One from Oḍdiyāna have been transcribed from golden scrolls by treasure-discoverers - like sons enjoying the riches of the father. [This, your work], too - in the same way as the handwriting of the treasurediscoverer is inseparable from the golden scroll - has been transcribed by yourself!" Accordingly, he strove to complete [correctly the works bearing the titles] "The Minor Nirvāna of the Qualified Lord" (i.e. bTsun pa Chos legs) and "The Small and Extensive Royal Genealogies" [and all] the individual names [of the rulers] mentioned [therein]. And not only that; it is said that his previous compositions, including the metrics of poetical writings and so forth were [all] executed by himself and thus transformed into a [set of his own] collected writings.

Also, the sequence, [i.e.] the succession in the ordering of the writings these were compiled [like] a continuous stream of water, with sometimes greater [works followed by] lesser, and sometimes lesser [by] greater, in an uncertain arrangement. Persons of great learning will have no occasion [to use] faulty words [against such an arrangement] ${ }^{18}$

See the catalogue of the collected writings of Chos dbang rgyal mtshan (as in note 17), fols. $4 \mathrm{~b} / 3-5 \mathrm{a} / 2$ (de ltar mnyam med dpal ldan bla ma'i dam pa'i gsung ngag dri ma med $p a$ / bka' 'bum rin po che dbang gi rgyal po'di nyid / byin rnams ni zhal bzhugs ring la bsgrigs pa yin cing / grub mtha' gshags ral ni zhal bzhugs dus bris pa yin la rin po cher sung (= gsung) zhu / da bar u rgyan rin po che'i gter chos gcig ni / gter ston rnams kyis shog ser las phab pa las / pha nor la bu spyad pa ltar / 'di yang gter ston gyis phyag ris / shog ser dang dbyer med pa las nyid kyis phab pa / de dang mtshungs bzhin / mtshan ldan rje'i mya ngan 'das chung dang / rgyal rabs che chung rnams kyang / mtshan so sos smos pa rnams klad du bzhugs pa ma gtogs / snyan sngags gyi sdeb sbyor sogs gong [5a] rtsom thams cad nyid kyis mdzad pas / bka' 'bum du 'gyur gsung ngo / go rim yang yi ger bkod pa rim bzhin chu babs su bsgrigs pa yin pas / mchog dman dang / dman mchog gi bsgrigs rim nges pa med pa la / mkhas pa chen po rnams kyis tshig skyon gyi skabs ma mchis so). According to the table of contents, the doxographical work with the short title gShags ral chen mo is contained in 
These details make it clear that the three volumes of the collected writings were compiled and written out during the lifetime of Chos dbang rgyal mtshan and that he had an active hand in the editorial process of producing the manuscripts of his own compositions. The blocks for the three-volume set were only carved after the master's death. According to the printing colophon of the biography, the donors came from the Himalayan valley of bTsum, already referred to as a regional source of paper, and a region where on earlier occasions the Bo dong pa monk had been actively involved in producing xylograph editions of Buddhist texts.

The act of transcribing the teachings of Padmasambhava can be considered as a standard for the correctness and authenticity of other handwritten material brought to light by treasure-discoverers. The allusion to it recalls Chos dbang rgyal mtshan's own involvement with treasurer-discoverers of the rNying ma pa school and the revelation of an ancient scroll he had discovered himself; the result of this find was written out and later incorporated into his collected writings. Another angle to be considered here is the impact the more widespread use of printing (and the growing awareness of conflicting readings it occasioned) had on editorial practices at the time. It is noteworthy that in the case of a representative of the flourishing block-print culture it is the model of the true treasure-discoverer transcribing the original golden scrolls that is summoned up. ${ }^{19}$

We do not have access to the majority of the doctrinal works of Chos dbang rgyal mtshan, and it would be particularly helpful to have all the writings of his that are known as the "cycle of catalogues and printing colophons" (dkar chag dang / spar byang gi skor) in order to further document the individual printing projects conducted under his supervision. In order to get an overview

the second volume of the collected writings. Mention is made as well to a chronicle of the rulers of Mang yul Gung thang in the third volume; see the work (as in note 16), fols. $2 \mathrm{~b} / 2$ \& $3 \mathrm{~b} / 3-4$ [= Appendix II]. A work by Chos dbang rgyal mtshan documenting the phase immediately before the death of bTsun pa Chos legs (known as the "Minor Nirvānan") is noted in the biography of the former; see Ehrhard (2000a, 27, note 10).

19 For the contacts Chos dbang rgyal mtshan had with such treasure-discoverers as Rig 'dzin mChog ldan mgon po (1497-1531) and Rig 'dzin bsTan gnyis gling pa (1480-1535), both of whose collected writings he had executed as block-print editions, see Ehrhard (2000a, 32-37 \& 40-42). During a stay in the region of lHo brag, the Bo dong pa monk had extracted a treasure text which found its way into the second volume of his collected writings; see the text Dug brtag pa dang bcos pa'i gdams ngag khyad par can in the catalogue (as in note 17), fol. 3a/6-b/1 [= Appendix II]. For the impact printing had on Tibetan textual criticism and scholarship and the implications for and influence on Tibetan intellectual and cultural practices in general, consult van der Kuijp (2013, 125-126). 
of both the available works and complete writings according to the catalogue, the corresponding list and a facsimile of the catalogue is reproduced below (see Appendix II).

\section{Conclusions}

The shift of a manuscript culture to a block-print culture in the region of Mang yul Gung thang can best be described as a change in media under which the old ways of codifying and transmitting Buddhist scriptures and teachings in the form of handwritten copies, far from becoming superfluous, continued to play a central role in textual production. As could be seen in the case of the two sets of collected writings from the Bo dong pa school, the individual works were first written out in manuscript form by expert scribes - sometimes even by the authors themselves - and were only later carved on wooden blocks. The expertise of the craftsmen and artists was grounded in their knowledge of the different scripts and the technical means of producing Buddhist artefacts. It was important, too, to receive financial assistance from royal patrons or local communities, who supported the activities of individual masters.

As could be seen in the early efforts of bTsun pa Chos legs to produce a set of collected writings and in the first stage of the codification of his own compositions, the manuscript medium was the dominant one, and even shortly before the time of his death the matter was still unsettled whether his compositions should be collected and made available as xylographs. It was obviously only after increased contacts with the royal court of Mang yul Gung thang that the means and resources could be marshalled to produce a complete print edition of his writings. In the case of Chos dbang rgyal mtshan, the expert Buddhist craftsman with close contacts to the royal court, we step over the threshold into a well-established block-print culture, one with its centre at the hermitage of Kun gsal sgang po che. Here again, one can observe the delivery of its products to Central Tibet and visits of religious and political authorities to Mang yul Gung thang in order to have collected writings brought out as xylograph editions. This situation would explain in part why the collected writings of the Bo dong pa monk became available as block prints so soon after his death. ${ }^{20}$

The hermitage of Kun gsal sgang po che as a vibrant centre of printing activities in Mang yul Gung thang, along with a visit paid to it by an official known as sDe pa skyid gshongs pa nang so, was first sketched in Ehrhard (2000a, 39, note 29); compare Ehrhard (in press) concerning its print edition of the collected writings of 'Ba ra ba sPrul sku Nam mkha' rgyal mtshan (1475-1530) from the year 1534 executed on the visitor's behalf. During this 
One of the differences between handwritten and printed texts lies in the latter's mode of dissemination and the number of copies that could be made available to a wider audience. We still do not know much about the number of prints produced of such collected writings as the two examples of the Bo dong pa school and how they were circulated. It seems that everything was largely confined to a fairly local scale, as can be inferred from the number of original xylographs which have surfaced up to now. As documented by the initial xylographs of Phyogs las rnam rgyal, the technology of printing was introduced in south-western Tibet in the early 15 th century, and actual printing ventures were supported by the various ruling houses. The craft exerted a greater impact in the 16th century with the establishment of individual workshops and a network of Buddhist artists and craftsmen, as documented in the historiography of the print medium in Mang yul Gung thang. The compilation of individual works of great teachers into coherent collections has always played an important role in the intellectual and religious life of Tibetan Buddhists, and this is just as true, if not more so, of texts chosen to be reproduced as xylographs.

\section{Appendix I: Collected Works of bTsun pa Chos legs}

Block prints that contain a marginal volume letter:

Vol. Ka dPal ldan bla ma dam pa chos legs mtshan can gyi rnam thar yon tan 'brug sgra, 150 fols.

NGMPP reel nos. L 66/7-L 67/1. Also available in "Bod kyi shing spar lag rtsal gyi byung rim mdor bsdus" (as in note 4), pp. 40-42.

Vol. Kha Thugs rje chen po'i dmar khrid don tshan Inga pa, 125 fols.

NGMPP reel no. L $263 / 1$

gSang spyod rnal lam ma, 14 fols. NG MPP reel no. L 340/14

Vol. Ga (not available)

Vol. Nga (not available)

Vol. Ca rDo rje slob dpon gyis bya ba'i rim pa, 38 fols.

NGMPP reel no. L 340/5

Kun rig la brten pa'i zhi ba'i sbyin bsreg, 19 fols.

NGMPP reel no. L $878 / 3$

Vol. Cha (not available)

period one can also witness in the southern regions of the kingdom an increased production of xylograph editions of hagiographical works and reprints of Buddhist classics; see Sernesi (2011, 184-205). 
Block prints lacking a marginal volume letter:

Grol lam gsal bar byed pa snying gtam rin po che’i phreng ba, 239 fols.

NGMPP reel nos. L 390/7-L 391/1 \& AT 150/7-150/11

Phyag rgya chen po'i khrid / skal bzang gso pa'i bdud rtsi snying po bcud bsdus, 81 fols. (individual margin: e)

NGMPP reel no. AT 161/21-162/1

Phyag rgya chen po'i dka' ba'i gnas gsal byed sgron me, 25 fols. (individual margin. vam)

NGMPP reel no. AT 161/21-162/1

Nyams yig mani lu gu rgyud, 37 fols. (individual margin: ka)

NGMPP reel no. AT 161/21-162/1

Nges don dgongs pa kun 'dus, 9 fols.

NGMPP reel no. L $189 / 2$

Manuscripts lacking a marginal volume letter:

rDzogs pa chen po kun bzang dgongs pa rab gsal, 213 fols.

NGMPP reel no. L 492/1

Shes rab gtso bor gyur pa'i zab mo dbu ma rnam par bzhag pa, 137 fols.

NGMPP reel no. L 39o/5-6

Thabs gtso bor gyur pa mi shig pa'i (= shigs pa’i) rnam par bzhag pa, 60 fols.

NGMPP reel no. L 390/5-6

\section{Appendix II: Collected Works of Chos dbang rgyal mtshan}

Block prints containing a marginal volume letter:

Vol. Ka mTshan ldan bla ma dam pa mnyam med chos dbang rgyal mtshan gyi rnam par thar pa / rin po che nor bu'i phreng ba, 129 fols.

NGMPP reel no. L 66/5 \& L 389/13-L 390/1

mTshan ldan bla ma dam chos dbang rgyal mtshan gyi mgur 'bum, 212 fols.

NGMPP reel no. L 17/4, 212 fols. (incomplete) \&

241 fols., NGMPP reel no. L 65/5 (manuscript)

- mNyam med chos dbang rgyal mtshan gyi gsung ngag thor bu, $5^{8}$ fols.

NGMPP reel nos. L $17 / 6$ and L 66/6

Vol. Kha Phyag rgya chen po lhan gcig skyes sbyor gyi khrid rgyab, 12 fols.

NGMPP reel no. L $17 / 2$

mTshan ldan bla ma dam pa'i gsung 'bum las / phyag rgya chen po'i man ngag

bdud rtsi'i gter mdzod, 10 fols. 
NGMPP reel no. L $17 / 5$

mNyam med chos dbang rgyal mtshan gyi sku bstod, 3 fols.

NGMPP reel no. L. 17/3

Vol. Ga (not available)

Contents of the Collected Writings according to dKar chag mun sel sgron me, fols. $2 a / 4-3 b / 4$ :

de las thog mar ka pa la / rnam par thar pa nor bu rin po che'i phreng ba dang / mgur 'bum zhal gdams bslab bya'i skor rnams dang gsung ngag thor bu'i skor rnams bzhugs /.... /

kha pa la / gsol 'debs dang / [2b] bstod pa'i skor / mtshan ldan gyi bla ma dam pa chos lags (= legs) mtshan can gyigsang ba'i rnam thar dang / myangan'das chung / dpal ldan bla ma dam pa rab 'byams pa mngon pa'i seng ge'i rnam thar ngo mtshar gyi dga' ston / chos thams cad gyi spyi babs gshag ral chen mo gzhi lam 'bras bu gsum gyi don bshad / u rgyan gyis gsungs pa'i rgan mo 'dzub btsugs kyi khrid zin bris su bkod pa / rdzogs pa chen po dgongs pa zang thal gyi zin bris / rdzogs pa chen po gzhi lam 'bras gsum gyi dka' ba nye gnas kyi zin bris / yang gsang rdzogs pa chen po'i thun mong ma yin pa'i zab bris su bkod pa / mngon sum 'od gsal nor bu'i do shal / rdo rje drag po rtsal gyi dbang chog ngag 'don ma / ma 'ongs lung bstan zin bris su mdzad pa / rnam pa kun mkhyen 'grel pa mthong grol 'brug sgra / phyag chen lnga ldan gyi zin bris / phyag chen Ihan cig skyes sbyor gyi zin bris / de nyid kyi khrid yig sa bcad zin bris / de nyid kyi khrid rgyab tshigs bcad ma / phyag rgya chen po'i man ngag bdud rtsii gter mdzod ces bya ba / thugs rje chen po'i smar khrid don tshan [3a] Inga pa'i sa bcad / dangs ma mi shigs pa khyad par gsum ldan gyi rnam bzhag / bla ma dam pa'i gsung rgyan zin bris rnams bzhugs //... .

ga pa la / chos khungs btsun zhing gdams ngag la yid che par bya ba'i phyir / chos bka'so so'i brgyud yig dang / gsan yig chos kyi rgya mtsho / dpal rdo rje sems dpa'i bsgom bzlas zab mo / kyai (= kye) rdo rjei lag len rnam nges las byung ba'i bzlas tshul / zab mo bdud kyi gcod yul shes rab ral grii nyam len rgyun khyer / bcom ldan das rdo rje jigs byed kyi mngon rtogs tshigs bcad ma / ni gu'i chos skor gyi phyag len dang / gsan yig zin bris / kun rig la brten pa'i rdo rje slob dpon gyi bya ba'i rim pa dga'ston / bsnyen gnas kyi sdom pa'i rnam bshad / rin chen phreng mchog / rgyal yum nyi khri'inges don smar bsdus / tha mal rjen pa'i ngo sprod gsal 'debs / mdo lung nyer mgo (= mkho) bsdus pa rin po che'i phreng ba / dug [3b] brtag pa dang bcos pa'i gdams pa khyad par can / mtshan ldan bla ma dharma sadhu'i bka' 'bum gsal byed dkar chag / zhang rin po che'i bka' 'bum gyi bzhugs byang / gsan yig dang bcas pa / skyes bdun ril bu'i phabs rta'i dkar chag gsal ba'i me long / dkar chag dang / spar byang gi skor rnams / gdan sa chen po gcer dga' na bzhugs pa'i mdo sde'i dkar chag / rgyal rabs kun las btus pa’i nyer mkho / phag mo gru pa / gzhis kha rin spungs / shar kha ba / g.yas ru byang gi gdung rabs / rabs bsdus legs bshad rin chen phreng mdzes rnams bzhugs so // 

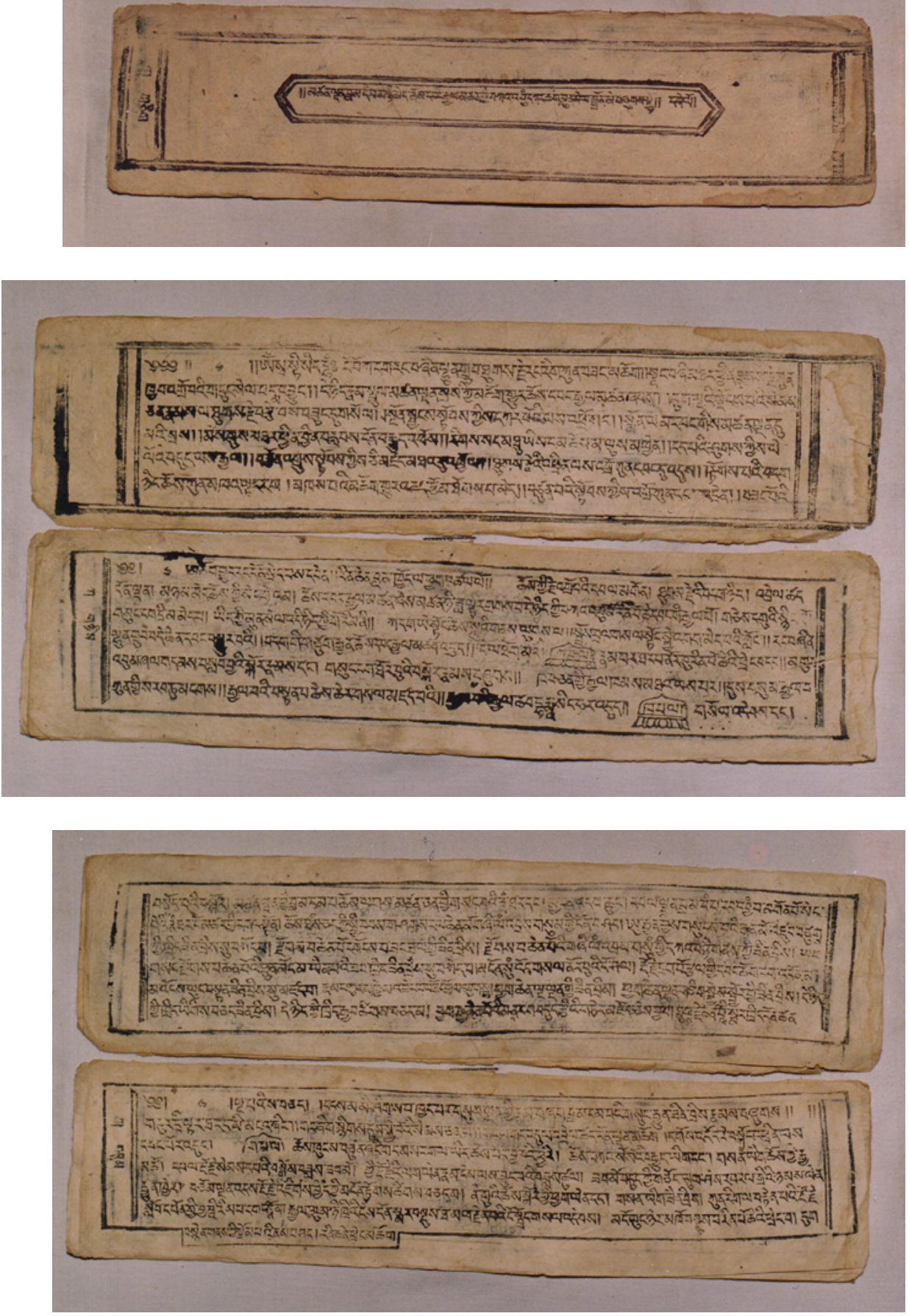

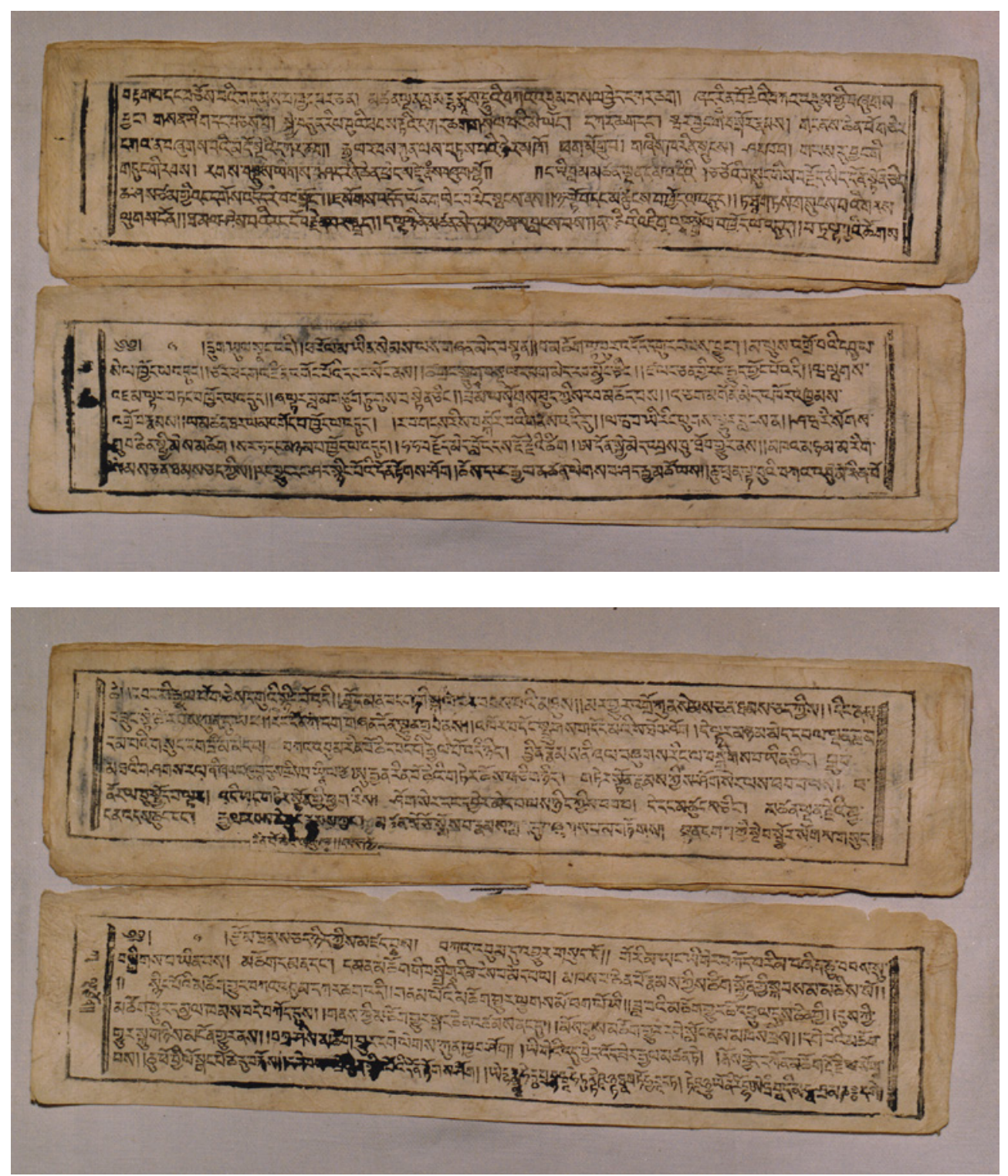

FIGURES 11.1-11.5 mTshan ldan bla ma dam pa mnyam med chos dbang rgyal mtshan gyi bka' 'bum dkar chag mun sel sgron me, 5 fols., NGM PP reel-no. L 389/3-39o/1. 


\section{References}

Chok Tenzin Monlam. 2005. "Life and Works of Bodong Chokley Namgyal." The Tibet Journal, 30: 3: 89-100.

Cüppers, C. 2010. “Some Remarks on Bka' 'gyur Production in 17th Century Tibet." In Edition, éditions: l'écrit au Tibet, evolution at devenir (= Collectanea Himalayica, 3), 115-128. Munich: Indus Verlag.

Cüppers, C. \& Ehrhard, F.-K. 2008. "Die Kupferplatten der Könige Ādityamalla und Punyamalla von Ya-tshe." In Tibetstudien: Festschrift für Dieter Schuh zum 65. Geburtstag, 37-42. Bonn: Bier'sche Verlags-Anstalt.

Czaja, O. 2013. Medieval Rule in Tibet: The rlangs Clan and the Political and Religious History of the Ruling House of Phag mo gru pa. With a Study of the Monastic Art of Gdan sa mthil, 2 vols. (= Österreichische Akademie der Wissenschaften, Phil.Hist. Klasse Denkschriften, 255 / Veröffentlichungen zur Sozialanthropologie, 20). Vienna: Verlag der Österreichischen Akademie der Wissenschaften.

Diemberger, H., Wangdu, P. Kornfield, M. \& Jahoda, C. 1997. Feast of Miracles: The Life and the Tradition of Bodong Chole Namgyal (1375/76-1451 AD) according to the Tibetan Texts "Feast of Miracles" and "The Lamp Illuminating the History of Bodong". Clusone: Porong Pema Chöding Ed.

Diemberger, H. 2009. "Chos kyi sgron ma's Life and the Bo dong pa Tradition: Discovery and Innovative Creativity in Buddhist Revival." In Ancient Treasures/ New Discoveries. PIATS 2006: Tibetan Studies: Proceedings of the Eleventh Seminar of the International Association for Tibetan Studies, Königswinter 2006 (= Beiträge zur Zentralasienforschung, 19), 97-124. Andiast: IITBs.

- 2012. "Holy Books as Ritual Objects and Vessels of Teaching in the Era of the 'Further Spread of the Doctrine' (bstan pa yang dar)." In Revisiting Rituals in a Changing Tibetan World (= Brill's Tibetan Studies Library, 30), 9-41. Boston / Leiden: Brill.

Diemberger, H. \& Clemente, M. 2013. "Royal Kingship, Patronage and the Introduction of Printing in Gung thang: From Chos kyi sgron ma to lHa btsun rin chen rnam rgyal." In Nepalica Tibetica: Festgabe für Christoph Cüppers, Vol. 1 (= Beiträge zur Zentralasienforschung, 28), 119-142. Andiast: IITBs.

Ehrhard, F.-K. 2000a. Early Buddhist Block Prints from Mang-yul Gung-thang (= Lumbini International Research Institute Monograph Series, 2). Lumbini: Lumbini International Research Institute.

- 20oob. Four Unknown Mahāmudrā Works of the Bo-dong-pa school (= Lumbini International Research Institute Facsimile Edition Series, 2). Lumbini: Lumbini International Research Institute.

- 2000c. "The Transmission of the AMar-khrid Tshem-bu lugs and the Mani ka' 'bum." In Vividharatnakarandaka: Festgabe für Adelheid Mette (= Indica et Tibetica, 37), 199-215. Swisttal-Odendorf: Indica et Tibetica Verlag. 
- 2002. Life and Travels of Lo-chen bSod-nams rgya-mtsho (= Lumbini International Research Institute, 3). Lumbini: Lumbini International Research Institute.

. 2012. "Gnas Rab 'byams pa byams pa phun tshogs (1503-1581) and his Contribution to Buddhist Block Printing." In This World and the Next: Contributions on Tibetan Religion, Science and Society. PIATS 2006: Proceedings of the Eleventh Seminar of the International Association for Tibetan Studies, Königswinter 2006 (= Beiträge zur Zentralasienforschung, 27), 149-176. Andiast: ІІтвs.

—. 2013. "The Royal Print of the Mani bka' 'bum: Its Catalogue and Colophon." In Nepalica-Tibetica: Festgabe für Christoph Cüppers, Vol. 1 (= Beiträge zur Zentralasienforschung, 28), 143-171. Andiast: IIт Bs.

—. In press. "Buddhist Hagiographies from the Borderlands: Further Prints from Mang-yul Gung-thang." In Manuscript and Xylograph Traditions in the Tibetan Cultural Sphere. Regional and Periodical Characteristics, edited by D. Wangchuk \& O. Almogi. (Series for Indian and Tibetan Studies.) Hamburg: University of Hamburg. Eisenstein, E. L. 1979. The Printing Press as an Agent of Change: Communication and Cultural Transformation in Early Modern Europe. 2 vols. Cambridge: Cambridge University Press.

-1983. The Printing Revolution in Early Modern Europe. Cambridge: Cambridge University Press.

Everding, K.-H. 2000. Das Königreich von Mang yul Gung thang: Königtum und Herrschergewalt im Tibet des 13.-17. Jahrhunderts (= Monumenta Tibetica Historica, 1:6 [1-2]). Bonn: VGH-Wissenschafts Verlag.

Jackson, D. P. 1989. The Early Abbots of Phan-yul Na-lendra: The Vicissitudes of a Great Tibetan Monastery in the 15th Century (= Wiener Studien zur Tibetologie und Buddhismuskunde, 25). Vienna: Arbeitskreis für Tibetische und Buddhistische Studien.

- 1990. "The Earliest Printing of Tsong-kha-pa's Works: The Old Dga'-ldan Editions." In Reflections on Tibetan Culture: Essays in Memory of Turrell V. Wylie (= Studies in Asian Thought and Religion, 12), 107-116. Lewiston / Queenston / Lampeter: Mellen.

Johns, A. 1998. The Nature of the Book: Print and Knowledge in the Making. Chicago \& London: University of Chicago Press.

Kragh, U.T. 2013. "The Significant Leap from Writing to Print: Editorial Modifications in the First Printed Edition of the Collected Works of Sgam po pa Bsod nams rin chen." Journal of the International Association of Tibetan Studies, 7: 365-423.

van der Kuijp, L. W. J. 2007. “The Tibetan Expression 'bod wooden door' (bod shing sgo) and its Probable Mongol Antecedents." In Historical and Philological Studies of China's Western Regions, 3: 89-134. 
2010. "Faulty Transmissions: Some Notes on Tibetan Textual Criticism and the Impact of Xylography." In Edition, éditions: l'écrit au Tibet, evolution et devenir (= Collectanea Himalayica, 3), 441-463. Munich: Indus.

- 2013. "Some Remarks on the Textual Transmission and Text of Bu ston Rin chen grub's Chos-'byung, a Chronicle of Buddhism in India and Tibet." Revue d'Études Tibétaines, 25: 111-189.

Schaeffer, K. R. 2009. The Culture of the Book in Tibet. New York \& Chichester, West Sussex: Columbia University Press.

- 2011. "The Printing Projects of Gtsang smyon He ru ka and His Disciples." In Mahāmudrā and the Bka'-brgyud Tradition. PIATS 20o6: Tibetan Studies Proceedings of the Eleventh Seminar of the International Association for Tibetan Studies, Königswinter 2006 (= Beiträge zur Zentralasienforschung, 25), 453-477. Andiast: IITBS.

Sernesi, M. 2010. "A Manual on Naropa's Six Yogas by Spyan snga Nyer gnyis pa (13861454): Tucci Tibetan Collection 1359". Indo-Iranian Journal, 53: 121-163.

- 2011. "A Continuous Stream of Merit: The Early Reprints of gTsang smyon Heruka's Hagiographical Works." Zentralasiatische Studien, 40: 170-237.

-2013/2014 (2015). "The Collected Sayings of the Master: On Authorship, Authorfunction, and Authority." Journal of the International Association of Buddhist Studies, 36/37: 459-498.

Smith, E. G. 2001. Among Tibetan Texts: History and Literature of the Himalayan Plateau. Boston: Wisdom Publications.

Sørensen, P. K. \& Hazod, G. 2007. Rulers of the Celestial Plain; Ecclesiastic and Secular Hegemony in Medieval Tibet: A Study of Tshal Gung-thang, 2 vols. (= Österreichische Akademie der Wissenschaften, Phil.-Hist. Klasse, Denkschriften, 361 / Veröffentlichungen zur Sozialanthropologie, 12). Vienna: Verlag der Österreichichen Akademie der Wissenschaften.

Vitali, R. 2012. A Short History of Mustang (1oth-15th Century). Kathmandu: Vajra Publications. 